\section{PP-049＼cjkstart協同的な推敲活動における筆名の使 用が書き手の意欲に与える効果}

○深谷 優子 ${ }^{1}$, 市川 洋子 ${ }^{2}$

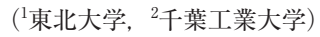

キーワード：協同, 作文, 筆名

協同的な活動は教授・学習場面をはじめとして様々な場面で導入され ている。協同する相手が同級生（ピア）などの知り合いや友人である場 合, 関係性悪化を懸念するあまり，協同的な活動や課題に十全に取り組 めない参加者が一定多数存在することが指摘されている。本研究では，ピ アレビュー方式の協同的な推敲活動を行う際に実名でなく筆名を用いる ことで，こうした書き手の懸念や不安が緩和されるのかを検討した。私 立大学 X で同じ課題探求セミナーを受講している 3 クラス計 75 名の学生 が筆名を用いて協同推敲に従事した。筆名は，指定された数字／任意の 数字 /任意の数字と単語, のいずれかに割り当てた。その結果, 実名よ りも作文やコメントがしやすかったと評価していた。また，自由記述よ り，筆名を用いることで，ピア（の名前）ではなく，コメントや作文の 内容により集中できたことが示唆された。筆名の匿名性と識別性が，参 加者の意欲や活動に与える影響について考察した。
PP-050

児童のインターネット使用態度とイ ンターネット依存傾向, スクールモ ラールの関連

○宅 幹子

(岡山大学)

キーワード：インターネット，インターネット依存，スクールモラール

子どものインターネット使用をめぐり多くの課題が指摘されているが, 学校現場では子どものインターネット使用状況は見えにくく, 実態把握 は難しい。本研究では, 児童のインターネット使用態度, トラブル経験, インターネット依存傾向，スクールモラールを調查し，学校での児童の 様子とインターネット使用状況との関連を検討することを目的とした。調 查対象は小学校 6 年生 236 名 (男子106名, 女子 122 名, 不明 8 名) であっ た。調查内容は, (1)児童のインターネット使用態度を問う項目 (6 項目), (2)览童のインターネット使用に扔けるトラブル経験（1 項目), (3)イン ターネット依存傾向（戸部・堀田（2010）によるインターネット依存傾 向尺度項目11項目について 4 段階評定を求め, 1 4 の評点を加算した もの），(4)スクールモラール尺度（河村，1999）であった。結果から, 男 子ではインターネット使用態度に問題を抱え, インターネット依存傾向 が強いほどスクールモラールの低下がみられたのに対して（中程度の相 関)，女子では変数間に男子ほどの関連性はみられず，使用態度に問題を 抱え, 依存傾向が強くても学校場面での適応に問題を生じるとはいえず より慎重な実態把握が必要と考えられる。

連絡先 E-mail：miyake@okayama-u.ac.jp

\section{PP-052＼cjkstart保育系短期大学生における心理学の 捉え方一講義を通した変化に注目し \\ て一} に促してもうまく使えない理由一行 動学と脳科学に基づく図表トレーニ ング効果の検証一

○綾部 宏明 ${ }^{1}$, マナロ エマニュエル 1.\#, 花木 規子 2 ,, , 藤田 弥世 ${ }^{1}$, 野村 理朗 ${ }^{1}$

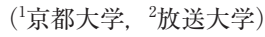

キーワード : 数学教育, 眓表, 脳血流量

図表は文章題解決に有効である。ところが，教師が図表の使い方を示 して教えても生徒は自発的に使わず，たとえ使っても効果的に解決でき ない傾向がある。近年，図表知識を教授して練習させると自発的な使用 が促され，正答率が向上することが実証された（Ayabe \& Manalo, 2018; Ayabe, Manalo, \& Hanaki, 2020)。しかし, 図表スキル習得のために必 要な指導構成要素は不明であり, 生理学的証拠も示されていない。本研 究では参加者16名（15.7 2 2.9才）に対して教授要因 3 水準（プレ 1 〔BL〕ープレ 2 〔表使用教示〕ーポスト〔表練習〕）を段階的に操作して, 表が解決に役立つと想定された数学文章題を与えた。そして, 表と解答 の完成度, 解答中の脳血流量（fNIRS）を測定した。その結果，プレ 2 で は表使用は高まったが $(p<.01)$ ，正答率は改善せず (n.s.)，ポストで初 めて改善した $(p<.01)$ 。また, プレ 2 では脳血流量は変わらなかったが (n.s.)，ポストでは左前頭領域で増加した（DLPFC, VLPFC; 各 $p<.05)$ 。 これらの結果は, 生徒に図表使用を求めるだけでは不十分で, 効果的な 使用には適切な練習が必要であることを示唆する。また，図表スキル習 得に伴う生理学的証拠も提供する。

連絡先 E-mail：ayabe@nips.ac.jp
○清水 一毅

(帝京学園短期大学)

キーワード：保育系短期大学生，心理学，捉え方

保育士養成課程において心理学が必修であることや，保育所保育指針 の中にみられる用語から保育の中で心理学が重要な立ち位置にあること が分かる。しかし, 本学では心理学という言葉のもつイメージにつられ, 身構えたり, 過剩に期待したりする学生が多くみられる。そこで本研究 では, 講義前後に打ける学生の持つ心理学のイメージおよび印象に残っ ている講義を調査することで, 本学における心理学教育の意義について の検討を行った。調査の結果, 講義前の学生の約半数は, 心理学を「メ ンタリズム」「心を読める」等と捉えていた。また心理学を学ぶにあたっ ての心情を述べた学生が $38 \%$ 㧍り, 不安や緊張, 期待感が影響している ことが分かった。講義後は「発達・行動・こころを考えるもの」と捉え る学生が多くみられ，講義を通して心理学の捉え方が学術的なものに変 化することが示唆された。さらに「印象に残っている講義」で挙がった キーワードは, “参加”“驚き”“納得感”“見通し”であった。この結果 は, これら 4 つのキーワードを含んだ講義が学生の心理学の捉え方に大 きく影響を及ぼしていることを示唆しているものと考えられる。 